\title{
SOCIAL AND TECHNICAL TRAINING IN WAR-TIME
}

$\mathrm{O}^{\mathrm{N}}$ NE of the novel features of the present situation is the presence in Great Britain of an army of more than two million soldiers largely without the soldier's proper task of fighting. The maintenance of the morale and welfare of large bodies of inactive forces is a major problem which has been too much for many commanders in the past. The problems it raises for us already demand close attention and will become the more searching with the shortening of the days as winter approaches. We cannot ignore the classical examples of the demoralization of idle armies.

While this is true, the question of the Army welfare should not be approached purely from the negative point of view of preventing demoralization. There is a general desire among the public of the country to alleviate any discomfort or monotony with which the troops are threatened. This desire has received official recognition, and a prime responsibility of the Army Welfare Organization established last November is that of directing this goodwill into the channels in which it can render the most effective service. If this is wisely and efficiently done we may well find that, without impairing that valuable tradition of the British Army of the responsibility of the regimental officer for the well-being of his men, we have not only effectively combated boredom but also in so doing developed an even closer and fuller sense of comradeship between the citizen and the forces, which should prove an invaluable asset in dealing with the post-War problems of reintegration and reconstruction.

Looked at even from this point of view, the organization of welfare work will involve many problems if gross disparities in different localities are to be avoided, either through the varying interests and resources of the Territorial county associations and the needs or conditions of the troops in different areas. Nor should it be considered that the problem is purely one of providing entertainment or amenities or facilities for games or sport. The universities in a number of areas have already turned their attention to the educational needs of the troops in the areas they serve, by providing programmes of lectures. Such extramural work may well require wide extension as part of an organized attempt to see that the minds of those called to the colours do not stagnate or become set in service grooves.

The possibilities in this direction merit immediate exploration. Even if only a minority of the men desire these educational courses they deserve the best encouragement and some considered attempt to find the right kind of instruction. Moreover it should be remembered that in many areas the men will be well outside the normal radius of a university, and if the whole country is to be covered effectively some scheme of co-operation may well have to be devised between the universities themselves, as well as between them and the army welfare authorities. Steps are now being taken in connexion with this (see NATURE of September 21, p. 396).

Behind all such educational schemes, the provision of entertainment or sport, or of opportunities for pursuing hobbies such as gardening, carpentry, music, there is a deeper significance which should not be forgotten. If by using the goodwill and services of individual citizens or civil authorities already recognized, the War Office can find the gardens, the workshops, places for various kinds of music required, and in doing so encourage on the part of the citizen a keen sense of comradeship with his fellow citizens under arms, there is an equally important reverse side of the picture. The soldier in his turn may in the same process become the better fitted to take his place again in civil life after the War.

It is this sense of the possibilities which we have in such educational work or recreation activities of fitting men to take their place more readily and happily in the new social or industrial order to be established after the War that is all important. If we are really alive to the opportunities which confront us in this field and do not allow them to escape us, we may well find attention to what at the moment appears to be a secondary aim - that of preparing men and women to take their place efficiently and harmoniously in a new order-will also serve best the immediate task of eliminating boredom and preserving morale. The adaptability or flexibility of mind, no less than the wider outlook and the sense of social responsibility and ideal of service and fitness which are so important an element in training for modern warfare, are the same qualities upon which we must build a higher ideal and nobler conception of citizenship.

A like opportunity may well confront us in the training schemes for industrial workers for war needs which are being introduced by the Ministry of Labour. Whether we are concerned with the training schemes which are being initiated primarily to increase the numbers of highly skilled workers for the engineering factories for munition production, with the training of workers displaced from 
less essential industries or occupation for munition work at the lower levels of skill, or with the training of women, the training cannot but contribute to increased mobility and flexibility of labour after the War. To the value of this as a national asset, reports of the Commissioners for the Special Areas testify.

It is well indeed that we should appreciate the long-term as well as the short-term advantage to the nation of such training schemes, for there are difficulties which are only likely to be overcome if the long view is kept carefully in mind and resolutely pursued. The experience gained in the Special Areas with the junior instruction centres and training schemes to meet local needs, even though these were limited to persons who had attained the age of eighteen years, shows that even on the worker's side there are prejudices to be overcome and personal or social obstacles to rehabilitation in the way. It is essential that the worker himself should be roused to a sense of the new and permanent opportunity now opening before him or her and become inspired with a new self-respect and sense of civic or social responsibility.

Nor are the obstacles only from the side of the worker. Training to the extent now demanded is beyond the resources of the Government training centres themselves, even if engineering employers respond freely to the Minister of Labour's appeal for the release of suitable men to become instructors in the training centres, the number of which Mr. Bevin hopes to extend from 19 to 40 . Besides this there has been initiated, in association with the President of the Board of Education and the Secretary for Scotland, a scheme of short courses of training through the technical colleges, by which it is hoped to add at least a further 50,000 to the 100,000 trainees coming from the training centres.

With all this there must be the fullest cooperation of employers in the training arrangements being set up not only in garages, maintenance shops and other shops with unused capacity, but also in the factories already on War production, if we are to secure the maximum utilization of our man-power essential to supply our wartime needs. Here is indeed a problem demanding technical knowledge as well as wise administration and loyal co-operation on the part of the management if a full and rapid solution is to be obtained. The introduction of training programmes into a works or other organization is no simple matter, as is well shown by F. Cushman in his recent book*. For all the American jargon which it contains,

* Training Procedure : a Discussion of the Problems encountered in Planning, Organizing, Operating and Maintaining Efficient Training. Programs in Industrial, Business and Public Service Organizations. By Frank Cushman. Pp. $x+230$. (New York : John Wiley a
Inc. : London : Chapman and Hall, Ltd., 1940.) 128. net. many of those called upon to arrange such training schemes might do worse than consult this book.

Besides his analysis of the factors and principles involved in developing and carrying out a programme of training, Mr. Cushman emphasizes the fundamental importance of the attitude of the executive. Mr. Bevin has already indicated in no uncertain manner that there are quarters in which this still leaves very much to be desired. The Government does not, however, as yet appear to realize that the nation is in no mood to tolerate any failure to apply compulsion to deal with recalcitrant elements who impede the maximum development of our War effort.

If, however, there are numerous technical details in such training schemes which must be worked out by careful scientific study, the long-range view must still be kept carefully in mind. Efficient production demands not merely skilled or technically proficient workers, but also workers who are keen on .their job and see its part in relation to the national effort. It is the conception of national service which lies behind the great response to the appeal to "Go to it" which has characterized these last few months.

For this reason alone our conception of training must embrace not merely technical fitness but social fitness also. Behind our training schemes there must be the planning which will ensure that immediate use is made of the skill of the trainees, that they are not kept waiting about for long periods while their skill and keenness both deteriorate. We must have clearly in mind the jobs for which we are training men and women, quantitatively as well as qualitatively.

Behind this short-term planning there must also be the more or less deliberate long-range planning in regard to the needs of the individual and of the community in the new order to follow the War. Such planning, even if little more at present than stimulating the ideal of service and citizenship, promoting adaptability and flexibility of mind and also skill, and the wise, sympathetic but determined handling of all those factors or intransigencies, whether in regard to the dilution of labour, professional privilege, co-operation in training schemes or the like, which no less in reconstruction than in this hour of peril are anti-social and inimical to the common weal, may well make the vital contribution to morale and drive which is all-important in a free community. If Mr. Eden and Mr. Bevin are alive to the wide opportunities which lie before them they may well make in these next few months a most significant contribution not merely to the winning of the War but also to the building of a new world. They will deserve the whole-hearted. support of every citizen of vision and good will in their efforts to make full use of these possibilities. 